\title{
A TIME HISTORY OF PRE- AND POST-BOMB RADIOCARBON IN THE BARENTS SEA DERIVED FROM ARCTO-NORWEGIAN COD OTOLITHS
}

\author{
John M Kalish ${ }^{1,2} \bullet$ Reidar Nydal $^{3} \bullet$ Kjell H Nedreaas $^{4} \bullet$ George S Burr $^{5} \bullet$ Gro L Eine $^{6}$ \\ ABSTRACT. Radiocarbon measured in seawater dissolved inorganic carbon (DIC) can be used to investigate ocean circula- \\ tion, atmosphere/ocean carbon flux, and provide powerful constraints for the fine-tuning of general circulation models \\ (GCMs). Time series of ${ }^{14} \mathrm{C}$ in seawater are derived most frequently from annual bands of hermatypic corals. However, this \\ proxy is unavailable in temperate and polar oceans. Fish otoliths, calcium carbonate auditory, and gravity receptors in the \\ membranous labyrinths of teleost fishes, can act as proxies for ${ }^{14} \mathrm{C}$ in most oceans and at most depths. Arcto-Norwegian cod \\ otoliths are suited to this application due to the well-defined distribution of this species in the Barents Sea, the ability to deter- \\ mine ages of individual Arcto-Norwegian cod with a high level of accuracy, and the availability of archived otoliths collected \\ for fisheries research over the past 60 years. Using measurements of ${ }^{14} \mathrm{C}$ derived from Arcto-Norwegian cod otoliths, we \\ present the first pre- and post-bomb time series (1919-1992) of ${ }^{14} \mathrm{C}$ from polar seas and consider the significance of these data \\ in relation to ocean circulation and atmosphere/ocean flux of ${ }^{14} \mathrm{C}$. The data provide evidence for a minor Suess effect of only \\ 0.2\% per year between 1919 and 1950 . Bomb ${ }^{14} \mathrm{C}$ was evident in the Barents Sea as early as 1957 and the highest ${ }^{14} \mathrm{C}$ value \\ was measured in an otolith core from a cod with a birth date of 1967 . The otolith ${ }^{14} \mathrm{C}$ data display key features common to \\ records of ${ }^{14} \mathrm{C}$ obtained from a Georges Bank mollusc and corals from the tropical and subtropical North Atlantic.
}

\section{INTRODUCTION}

General circulation models (GCMs) are considered the most effective means of understanding dynamics of carbon flux through the biosphere, but existing and future models require fine-tuning on the basis of spatially and temporally varying tracers. Cosmogenic and anthropogenic radiocarbon has the greatest potential to elucidate the complexities of both oceanic circulation and carbon flux between the atmosphere and ocean and are essential tools to constrain GCMs. These two sources of ${ }^{14} \mathrm{C}$ make it possible to investigate ocean mixing and $\mathrm{CO}_{2}$ flux on decadal to millenial time scales. However, the ability to apply the ${ }^{14} \mathrm{C}$ tracer to GCM validation is hampered by relatively poor spatial and temporal coverage of ocean ${ }^{14} \mathrm{C}$ data, particularly at high latitudes.

Uncertainties regarding the role of high latitude oceans in global climate and atmosphere/ocean carbon flux can be partly attributed to the lack of ocean time series from these regions. To date, there are no published pre- and post-bomb time series of ${ }^{14} \mathrm{C}$ from polar seas. The Barents Sea is of particular interest because of its role in the formation of Arctic waters (Midtun 1985) and as a sink for atmospheric $\mathrm{CO}_{2}$. The Norwegian Atlantic Current transports North Atlantic Water (NAW) along the west coast of Norway and into the shallow Barents Sea where the water experiences heat loss and increased salinity causing increased density in winter and decreased density in summer due to incorporation of ice melt-water (Aagaard and Carmack 1989). Sea-ice also plays a major role in the variable, but highly productive Barents Sea (Wassmann and Slagstad 1991).

Measurements of ${ }^{14} \mathrm{C}$ in seawater dissolved inorganic carbon (DIC) have been achieved since the 1950s and extensive measurements have been made as part of the Geochemical Ocean Sections Study (GEOSECS), North Pacific Experiment (NORPAX), Transient Tracers in the Ocean (TTO), South Atlantic Ventilation Experiment (SAVE), World Ocean Circulation Experiment (WOCE), and

\footnotetext{
${ }^{1}$ Fisheries and Marine Sciences Program, Bureau of Rural Sciences, Canberra, ACT. Email: John.Kalish@brs.gov.au. ${ }^{2}$ Division of Botany and Zoology, The Australian National University, Canberra, ACT, Australia

${ }^{3}$ Department of Physics, NTNU, N-7491 Trondheim, Norway

${ }^{4}$ Institute of Marine Research, N-5817 Bergen, Norway

${ }^{5}$ NSF-Arizona Accelerator Facility for Radioisotope Analysis, The University of Arizona, Tucson, Arizona 85721, USA

${ }^{6}$ Radiological Dating Laboratory, NTNU, N-7491, Trondheim, Norway
}

(C) 2001 by the Arizona Board of Regents on behalf of the University of Arizona RadiocarBon, Vol 43, Nr 2B, 2001, p 843-855

Proceedings of the 17 th International ${ }^{14} \mathrm{C}$ Conference, edited by I Carmi and E Boaretto 
others. Nevertheless, sampling is inadequate to provide appropriate constraints and further measurement of ocean ${ }^{14} \mathrm{C}$ has been achieved by the use of proxies. Several proxies of ${ }^{14} \mathrm{C}$ in seawater DIC have been established, but the most valuable are those capable of providing time series of ${ }^{14} \mathrm{C}$ variation over seasonal, annual, and decadal time scales. Hermatypic corals (e.g. Druffel 1989), bivalve molluscs (e.g. Weidman and Jones 1993), and fish otoliths (e.g. Kalish 1993) have all been used to determine pre- and post-bomb ${ }^{14} \mathrm{C}$; however each of these data sources has limitations. Corals are restricted to warm and shallow waters; bivalves are closely associated with sediments potentially affecting the dynamics of carbon incorporation, and interpretation of the annual sequence of zones can be problematic; and otoliths are relatively small and annual zones can be difficult to identify. Although there may be difficulties associated with each proxy, a combination of all groups is capable of providing broad spatial and temporal coverage of ${ }^{14} \mathrm{C}$ variability. Both otoliths (Kalish 1993) and bivalves (Weidman and Jones 1993) are of special interest due to their ability to provide data across all oceans. Fish otoliths are of further value because they can act as proxies over a range of ocean depths.

Time series of ${ }^{14} \mathrm{C}$ in seawater DIC at temperate latitudes have been derived relatively recently from accelerator mass spectrometry (AMS) analyses of selected regions of fish otoliths and bivalve shells. Records of a similar form from polar seas would be of value due to the critical nature of these systems in ocean circulation and global climate. The predictable nature of the distribution of juvenile Arcto-Norwegian cod (Gadus morhua), also called northeast Arctic cod, combined with the fact that otoliths are excellent proxies for ${ }^{14} \mathrm{C}$ in seawater DIC, make it possible to use this species' otoliths as recorders of ${ }^{14} \mathrm{C}$ variation in Norwegian Atlantic Current Water (NACW) in the southwestern Barents Sea. The Arcto-Norwegian cod fishery is among the largest fisheries in the world with catches exceeding one million tons in some years and considerable effort has been expended in developing a complete understanding of the species' biology and ecology. As part of this research effort the Institute of Marine Research in Bergen (Norway) has collected and archived otoliths from Arcto-Norwegian cod since the 1930s. Traditionally, these samples have been used to determine the age structure of the exploited cod population; however, the development of new applications based on otoliths (see Secor et al. 1995) has increased the value of these structures to a range of disciplines (e.g. Kalish 1995; Campana et al. 1996).

Early life-history of the Arcto-Norwegian cod stock has been studied intensively and spawning seasons, larval drift and juvenile nursery areas are well-described (see Dragesund and Gjøsaether 1988; Sundby 1994). Arcto-Norwegian cod spawn during March and April along the northern coast of Norway. The eggs and larvae are advected northward in the Norwegian Coastal Current and Norwegian Atlantic Current and, finally, into the Barents Sea. The distribution of juvenile Arcto-Norwegian cod less than one year of age (0-group fish) is largely determined by the extent of warm water, derived from the Norwegian Atlantic Current (NAC) in the southern and central Barents Sea (Figure 1) (Saetersdal and Loeng 1987). Annual surveys of the abundance and distribution of 0-group ArctoNorwegian cod in the Barents Sea region have been completed since 1965 (Anon 2000) and clearly demonstrate that these juvenile fish are restricted to the warmer waters south and west of the Polar Front (also called the Arctic Frontal Zone). Furthermore, maximum abundance of 0-group cod is clearly associated with the core of warm NACW as it enters the Barents Sea in all years (Figures 1 and 2).

\section{METHODS}

Arcto-Norwegian cod otoliths were selected from archives maintained at the Institute of Marine Research, Norway (IMR). The IMR has collected cod otoliths for fisheries management purposes 


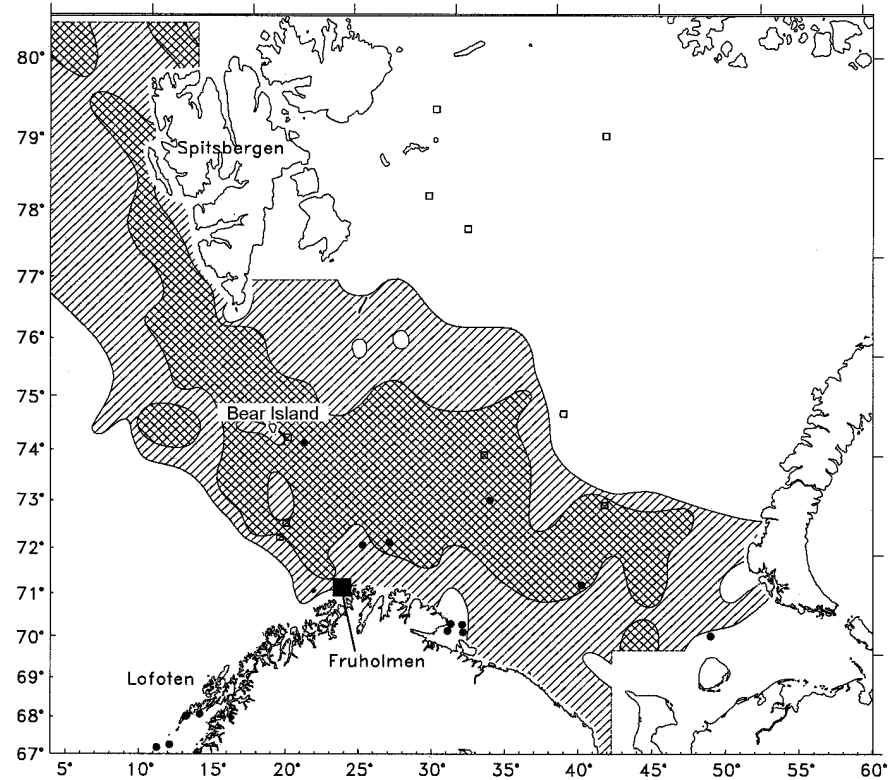

Figure 1 Distribution of 0 -group cod. The example is from August-September 1992 and shows a general distribution pattern of a good yearclass. The open squares show the sampling locations for measurements of ${ }^{14} \mathrm{C}$ in seawater DIC, the filled square shows the sampling location for atmospheric ${ }^{14} \mathrm{C}$ at Fruholmen, and the dots show the sampling locations of cod otoliths.

Figure 2 Main features of surface currents in the northeast Atlantic. The bold line indicates the mean position of the Arctic Frontal Zone (AFZ). The dotted line indicates where the position of the AFZ is most varying.

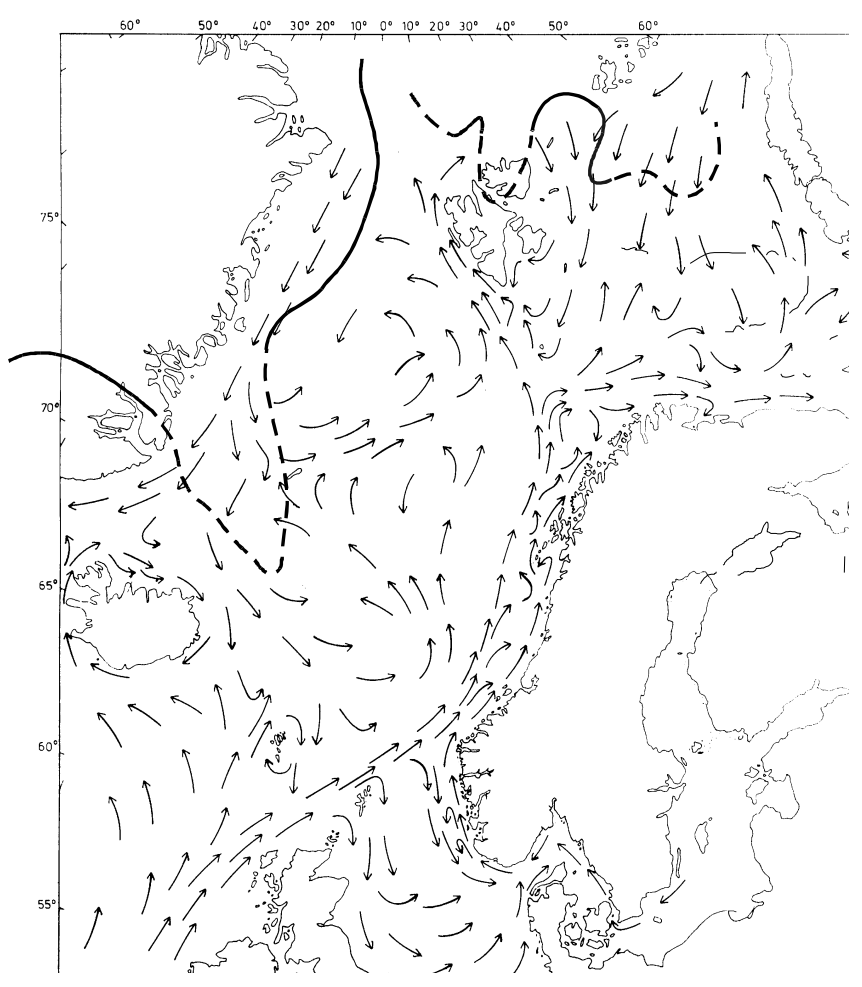


Table 1 Otolith and ${ }^{14} \mathrm{C}$ data from Arcto-Norwegian cod (Gadus morhua) collected in the Barents Sea. Values of ${ }^{14} \delta^{\mathrm{S}}{ }_{\mathrm{N}}$ are reported with \pm 1 standard deviation.

\begin{tabular}{|c|c|c|c|c|c|c|c|c|c|c|c|}
\hline $\begin{array}{l}\text { Sample nr } \\
\text { (Arizona) }\end{array}$ & $\begin{array}{l}\text { Sample nr } \\
\text { (ANU) }\end{array}$ & $\begin{array}{l}\text { Collection } \\
\text { location }\end{array}$ & $\begin{array}{l}\text { Collection } \\
\text { date }\end{array}$ & $\begin{array}{l}\text { Birth } \\
\text { date }\end{array}$ & $\begin{array}{l}\text { Fish } \\
\text { age }\end{array}$ & Sex & $\begin{array}{l}\text { Otolith } \\
\text { weight } \\
\text { (g) }\end{array}$ & $\begin{array}{c}\text { Sample } \\
\text { weight } \\
(\mathrm{mg})\end{array}$ & $\begin{array}{l}{ }^{14} \delta^{S_{N}} \\
(\% o)\end{array}$ & $\begin{array}{c} \pm \text { error } \\
(\% o)\end{array}$ & $\begin{array}{l}\delta^{13} \mathrm{C} \\
(\% o)\end{array}$ \\
\hline AA 15855 & ANU 1 & $\mathrm{~N} 67^{\circ} 30^{\prime} \mathrm{E} 11^{\circ} 40^{\prime}$ & 19-Apr-34 & 1919 & 15 & $f$ & 0.9818 & 18.2 & -48.9 & 5.4 & -2.2 \\
\hline AA 15856 & ANU 2 & $\mathrm{~N} 67^{\circ} 30^{\prime} \mathrm{E} 11^{\circ} 40^{\prime}$ & 19-Apr-34 & 1920 & 14 & $\mathrm{~m}$ & 0.8018 & 16.3 & -45.4 & 5.7 & -2.4 \\
\hline AA 15857 & ANU 3 & $\mathrm{~N} 67^{\circ} 30^{\prime} \mathrm{E} 11^{\circ} 40^{\prime}$ & 19-Apr-34 & 1925 & 9 & $\mathrm{~m}$ & 0.5321 & 17.0 & -50.8 & 4.7 & -2.7 \\
\hline AA 15858 & ANU 4 & $\mathrm{~N} 67^{\circ} 30^{\prime} \mathrm{E} 11^{\circ} 40^{\prime}$ & 22-Mar-39 & 1930 & 9 & $\mathrm{~m}$ & 0.6871 & 17.4 & -52.3 & 4.0 & -2.0 \\
\hline AA 15859 & ANU 5 & $\mathrm{~N} 70^{\circ} 20^{\prime} \mathrm{E} 31^{\circ} 20^{\prime}$ & 6-Jun-39 & 1933 & 6 & $f$ & 0.3372 & 18.2 & -59.6 & 4.1 & -2.4 \\
\hline AA 15860 & ANU 6 & $\mathrm{~N} 70^{\circ} 20^{\prime} \mathrm{E} 31^{\circ} 20^{\prime}$ & 6-Jun-39 & 1934 & 5 & $f$ & 0.4138 & 18.2 & -54.4 & 4.6 & -3.2 \\
\hline AA 15861 & ANU 7 & $\mathrm{~N} 67^{\circ} 42^{\prime} \mathrm{E} 12^{\circ} 20^{\prime}$ & 30-Mar-46 & 1935 & 11 & - & 0.8089 & 18.6 & -55.0 & 4.5 & -2.8 \\
\hline AA 15862 & ANU 8 & $\mathrm{~N} 67^{\circ} 42^{\prime} \mathrm{E} 12^{\circ} 20^{\prime}$ & 21-Mar-47 & 1940 & 7 & $\mathrm{~m}$ & 0.4939 & 16.4 & -49.0 & 4.5 & -3.2 \\
\hline AA 15863 & ANU 9 & $\mathrm{~N} 73^{\circ} 00^{\prime} \mathrm{E} 34^{\circ} 00^{\prime}$ & 27-Apr-50 & 1945 & 5 & - & 0.2802 & 18.6 & -53.3 & 4.4 & -2.2 \\
\hline AA 15864 & ANU 10 & $\mathrm{~N} 68^{\circ} 00^{\prime} \mathrm{E} 13^{\circ} 40^{\prime}$ & 27-Mar-55 & 1950 & 5 & $f$ & 0.5357 & 18.5 & -55.2 & 4.0 & -2.8 \\
\hline AA 15865 & ANU 11 & $\mathrm{~N} 68^{\circ} 03^{\prime} \mathrm{E} 13^{\circ} 50^{\prime}$ & 16-Mar-60 & 1955 & 5 & $\mathrm{~m}$ & 0.5585 & 18.5 & -43.8 & 4.2 & -2.8 \\
\hline AA 15866 & ANU 12 & $\mathrm{~N} 68^{\circ} 03^{\prime} \mathrm{E} 13^{\circ} 50^{\prime}$ & 4-Mar-63 & 1957 & 6 & - & 0.5113 & 16.7 & -24.1 & 4.1 & -2.5 \\
\hline AA 15867 & ANU 13 & $\mathrm{~N} 67^{\circ} 42^{\prime} \mathrm{E} 12^{\circ} 20^{\prime}$ & 1-Mar-66 & 1959 & 7 & $f$ & 0.4701 & 19.6 & -31.8 & 4.1 & -3.2 \\
\hline AA 15868 & ANU 14 & $\mathrm{~N} 67^{\circ} 42^{\prime} \mathrm{E} 12^{\circ} 20^{\prime}$ & 23-Mar-68 & 1961 & 7 & $f$ & 0.4632 & 17.9 & 9.1 & 4.4 & -2.3 \\
\hline AA 15869 & ANU 15 & $\mathrm{~N} 74^{\circ} 20^{\prime} \mathrm{E} 21^{\circ} 50^{\prime}$ & 6-Sep-68 & 1963 & 5 & $f$ & 0.4263 & 14.6 & 14.5 & 4.0 & -3.4 \\
\hline AA 15870 & ANU 16 & $\mathrm{~N} 68^{\circ} 10^{\prime} \mathrm{E} 14^{\circ} 30^{\prime}$ & 26-Mar-72 & 1965 & 7 & $\mathrm{~m}$ & 0.564 & 18.2 & 80.7 & 5.9 & -2.3 \\
\hline AA 15871 & ANU 17 & $\mathrm{~N} 71^{\circ} 25^{\prime} \mathrm{E} 24^{\circ} 50^{\prime}$ & 27-Apr-72 & 1967 & 5 & $f$ & 0.297 & 17.3 & 136.2 & 3.8 & -2.7 \\
\hline AA 15872 & ANU 18 & $\mathrm{~N} 71^{\circ} 25^{\prime} \mathrm{E} 24^{\circ} 50^{\prime}$ & 27-Apr-72 & 1969 & 3 & $f$ & 0.0956 & 15.5 & 91.7 & 4.7 & -2.5 \\
\hline AA 15873 & ANU 19 & $\mathrm{~N} 71^{\circ} 30^{\prime} \mathrm{E} 40^{\circ} 42^{\prime}$ & 2-Apr-74 & 1971 & 3 & $\mathrm{~m}$ & 0.1292 & 18.2 & 76.3 & 3.9 & -2.4 \\
\hline AA 15875 & ANU 21 & $\mathrm{~N} 70^{\circ} 45^{\prime} \mathrm{E} 32^{\circ} 20^{\prime}$ & 21-Jan-77 & 1975 & 2 & $\mathrm{~m}$ & 0.1021 & 19.6 & 110.5 & 4.1 & -2.8 \\
\hline AA 15876 & ANU 22 & $\mathrm{~N} 72^{\circ} 20^{\prime} \mathrm{E} 27^{\circ} 20^{\prime}$ & 8-Feb-83 & 1980 & 3 & $\mathrm{f}$ & 0.0971 & 14.9 & 86.9 & 4.0 & -3.5 \\
\hline AA 15877 & ANU 23 & $\mathrm{~N} 70^{\circ} 48^{\prime} \mathrm{E} 31^{\circ} 57^{\prime}$ & 2-Feb-87 & 1985 & 2 & $\mathrm{~m}$ & 0.064 & 14.0 & 79.3 & 4.0 & -2.5 \\
\hline AA 15878 & ANU 24 & $\mathrm{~N} 72^{\circ} 10^{\prime} \mathrm{E} 25^{\circ} 50^{\prime}$ & 28-Feb-92 & 1990 & 2 & $\mathrm{~m}$ & 0.0665 & 14.8 & 57.8 & 7.0 & -3.4 \\
\hline AA 19650 & ANU 26 & $\mathrm{~N} 71^{\circ} 25^{\prime} \mathrm{E} 24^{\circ} 50^{\prime}$ & 27-Apr-72 & 1967 & 5 & $\mathrm{~m}$ & 0.3316 & 17.9 & 121.9 & 6.1 & -3.0 \\
\hline AA 19651 & ANU 27 & $\mathrm{~N} 71^{\circ} 25^{\prime} \mathrm{E} 24^{\circ} 50^{\prime}$ & 27-Apr-72 & 1969 & 3 & $\mathrm{~m}$ & 0.1015 & 18.5 & 99.4 & 5.3 & -2.9 \\
\hline AA 19652 & ANU 28 & $\mathrm{~N} 71^{\circ} 30^{\prime} \mathrm{E} 40^{\circ} 42^{\prime}$ & 5-Apr-74 & 1971 & 3 & $\mathrm{~m}$ & 0.0945 & 19.1 & 109.6 & 7.4 & -1.8 \\
\hline
\end{tabular}


Table 1 Otolith and ${ }^{14} \mathrm{C}$ data from Arcto-Norwegian cod (Gadus morhua) collected in the Barents Sea. Values of ${ }^{14} \delta^{\mathrm{S}}{ }_{\mathrm{N}}$ are reported with \pm 1 standard deviation (Continued).

\begin{tabular}{|c|c|c|c|c|c|c|c|c|c|c|c|}
\hline $\begin{array}{l}\text { Sample nr } \\
\text { (Arizona) }\end{array}$ & $\begin{array}{l}\text { Sample nr } \\
\text { (ANU) }\end{array}$ & $\begin{array}{l}\text { Collection } \\
\text { location }\end{array}$ & $\begin{array}{c}\text { Collection } \\
\text { date }\end{array}$ & $\begin{array}{l}\text { Birth } \\
\text { date }\end{array}$ & $\begin{array}{l}\text { Fish } \\
\text { age }\end{array}$ & Sex & $\begin{array}{c}\text { Otolith } \\
\text { weight } \\
(\mathrm{g})\end{array}$ & $\begin{array}{c}\text { Sample } \\
\text { weight } \\
(\mathrm{mg})\end{array}$ & $\begin{array}{c}{ }^{14} \delta^{S_{N}} \\
(\% o)\end{array}$ & $\begin{array}{c} \pm \text { error } \\
(\% o)\end{array}$ & $\begin{array}{l}\delta^{13} \mathrm{C} \\
(\% o)\end{array}$ \\
\hline AA 19654 & ANU 30 & $\mathrm{~N} 70^{\circ} 15^{\prime} \mathrm{E} 32^{\circ} 30^{\prime}$ & 5-May-34 & 1925 & 9 & - & 0.8585 & 18.8 & -57.5 & 5.9 & -2.7 \\
\hline AA 19655 & ANU 31 & $\mathrm{~N} 70^{\circ} 15^{\prime} \mathrm{E} 32^{\circ} 30^{\prime}$ & 5-May-34 & 1925 & 9 & - & 0.7243 & 19.2 & -55.9 & 3.1 & -2.4 \\
\hline AA 19656 & ANU 32 & $\mathrm{~N} 73^{\circ} 00^{\prime} \mathrm{E} 34^{\circ} 00^{\prime}$ & 27-Apr-50 & 1945 & 5 & $\mathrm{~m}$ & 0.2166 & 16.7 & -60.4 & 3.4 & -3.2 \\
\hline AA 19657 & ANU 33 & $\mathrm{~N} 70^{\circ} 00^{\prime} \mathrm{E} 49^{\circ} 00^{\prime}$ & 21-Aug-93 & 1992 & 1 & - & 0.0182 & 14.5 & 57.1 & 3.7 & -2.9 \\
\hline
\end{tabular}


since the 1930s. These otoliths had been used to estimate the age of individual fish based on the quantification of opaque and translucent zones in sectioned otoliths. The method of age estimation for this species has been validated (Rollefsen 1933; Kalish et al. 1995) and only otoliths that could be interpreted with confidence were used in subsequent analyses. Otoliths had been stored dry in paper envelopes and, in some cases, had been collected as early as 1934 (Table 1). Samples were selected to span the greatest time period and included otoliths from 14 fish spawned prior to the presence of detectable bomb ${ }^{14} \mathrm{C}$ in the ocean $(1955)$ and 17 fish spawned during the "post-bomb" period (Table 1). The sample collection locations for the cod otoliths are shown in Figure 1.

Calcium carbonate deposited within the first year of the fish's life was isolated by sculpting one sagitta from each fish with a fine dental-type drill. This was achieved by "sculpting" from the larger otolith, an otolith that was representative of a cod of about one year of age. The final product was a single piece of otolith aragonite. Sample weights ranged from about 14.0 to $19.6 \mathrm{mg}$ (Table 1). This material would provide ${ }^{14} \mathrm{C}$ data indicative of Barents Sea DIC during the year of birth for an individual fish. Otolith carbonate was converted to $\mathrm{CO}_{2}$ by reaction in vacuo with $85 \%$ phosphoric acid. The CO2 was then sublimed into flame-sealed glass tubes for further treatment and measurement at the NSF-Arizona Accelerator Facility for Radioisotope Analysis. An aliquot of the $\mathrm{CO}_{2}$ was used to determine $\delta^{13} \mathrm{C}$ by mass spectrometry for each sample and the remaining $\mathrm{CO}_{2}$ was graphitized for analysis of ${ }^{14} \mathrm{C}$. ${ }^{14} \mathrm{C}$ levels in each sample were determined by accelerator mass spectrometry (AMS). In order to obtain a precision of 4-5\%o, several accelerator targets were applied (Donahue et al. 1990). ${ }^{14} \mathrm{C}$ is here reported in ${ }^{14} \delta^{\mathrm{S}}{ }_{\mathrm{N}}$ values, given in permil deviation from the recent standard (the oxalic acid at 1950) when corrected for age and isotopic fractionation $\left(\delta^{13} \mathrm{C}\right)$. This ${ }^{14} \delta^{\mathrm{S}}{ }_{\mathrm{N}}$ symbol recently introduced by Mook and van der Plicht (1999), is the same as the $\Delta^{14} \mathrm{C}$ symbol (Stuiver and Polach 1977) for geochemical samples, and includes correction for isotopic fractionation $\left(\delta^{13} \mathrm{C}\right)$ and for decay to 1950 AD.

\section{RESULTS}

${ }^{14} \mathrm{C}$ data obtained from the otoliths of Arctic cod with birth dates between 1919 and 1992 display general trends similar to those presented in other time series of ocean ${ }^{14} \mathrm{C}$ (Figure 3; Table 1). The average pre-bomb (1919-1950) ${ }^{14} \delta^{\mathrm{S}}{ }_{\mathrm{N}}$ value in the Barents Sea was $-53.8 \%$ and increased to a maximum of $134.2 \%$ in 1967 . During the late 1960 s until $1975{ }^{14} \mathrm{C}$ concentration appears highly variable and a secondary peak in ${ }^{14} \delta_{\mathrm{N}}^{\mathrm{S}}$ of $110.5 \%$ occurred in 1975 . The decline in ${ }^{14} \delta^{\mathrm{S}}{ }_{\mathrm{N}}$ from $1919-$ 1950 suggests a Suess effect of about $0.2 \%$ per year in the Barents Sea. However, based on linear regression the trend is not significant $(n=14, p=0.13)$. There is good evidence of bomb ${ }^{14} \mathrm{C}$ in the 1957 sample, which had a ${ }^{14} \delta^{\mathrm{S}}{ }_{\mathrm{N}}$ value of $-24.1 \%$, 30\% greater than the mean of pre-bomb measurements and $20 \%$ greater than the datum from $1955 .{ }^{14} \delta^{\mathrm{S}}{ }_{\mathrm{N}}$ declined linearly $\left(\mathrm{n}=5, \mathrm{r}^{2}=0.97, \mathrm{p}=0.002\right)$ from 1973 until 1992 at the rate of $3.1 \%$ per year.

\section{DISCUSSION}

\section{Comparison with High Latitude Ocean $\Delta$ Records}

Previous measurements of ${ }^{14} \mathrm{C}$ made directly on seawater DIC or through proxies (e.g. bivalve shells) in north polar latitudes have provided only snapshots of ${ }^{14} \mathrm{C}$ variability in this region. Data from the otolith-based Barents Sea time series of ${ }^{14} \mathrm{C}$ agree closely with past measurements made in the region directly on seawater DIC or through proxies, notably molluscan $\mathrm{CaCO}_{3}$ (Table 2 of other data from Barents Sea region; Figure 3). These results, coupled with the well-defined distribution of 0-group Arcto-Norwegian cod, provide strong support for the hypothesis that these data can serve as a measure of ${ }^{14} \mathrm{C}$ in NACW of the southwestern Barents Sea. 


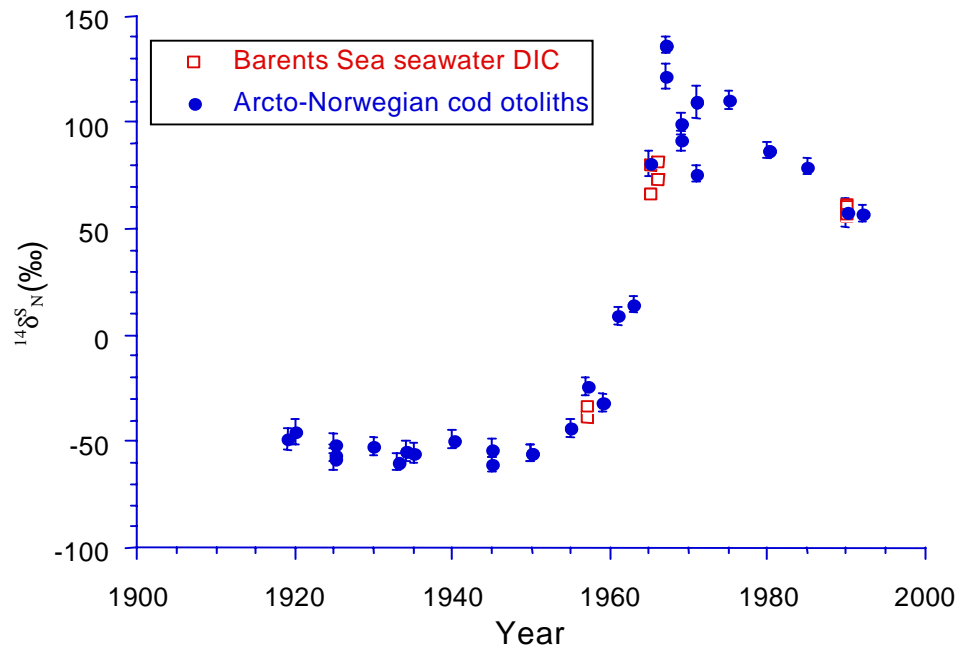

Figure $3{ }^{14} \mathrm{C}$ data $\left({ }^{14} \delta^{\mathrm{S}}\right)$ obtained from Arcto-Norwegian cod otoliths (this paper) and Barents Sea seawater (Østlund and Engstrand 1963; Nydal et al. 1991, 1998).

Mangerud and Gulliksen (1975) reported mean pre-bomb ${ }^{14} \delta^{\mathrm{S}}{ }_{\mathrm{N}}$ of $-57 \pm 4 \%$ and $-61 \pm 4 \%$ for northern Norway and Spitsbergen, respectively. These estimates were based on a range of bivalve mollusc species collected between 1857 and 1926 (Table 2). Therefore, these estimates are most comparable to the earliest cod otolith data presented in this study. Mean ${ }^{14} \delta^{\mathrm{S}}{ }_{\mathrm{N}}$ value in otoliths from cod spawned between 1919 and 1925 was $-51.7 \pm 5 \%$ o $(n=5)$ which is not significantly different from the mean based on mollusc shells from northern Norway.

${ }^{14} \mathrm{C}$ data from several locations in the Barents (Nydal et al. 1991; Nydal 1998), Norwegian and Greenland (Gislefoss et al. 1995; Nydal and Gislefoss 1996) Seas provide independent validation of otolith ${ }^{14} \mathrm{C}$. The majority of these data were collected between 1989 and 1992. Several measurements were, however, made during the 1950s and 1960s. Barents Sea ${ }^{14} \delta^{\mathrm{S}} \mathrm{N}$ in seawater DIC was $-35.8 \pm 3.4 \%$ in July 1957 (Table 2) and demonstrates that bomb ${ }^{14} \mathrm{C}$ was detectable in that region in the early phases of intensive atmospheric testing of nuclear weapons. Cod otolith ${ }^{14} \delta^{\mathrm{S}}{ }_{\mathrm{N}}$ was $-25.8 \pm 4.1 \%$ in 1957 , only slightly higher than that measured directly on seawater DIC in the same year, however, ${ }^{14} \delta^{\mathrm{S}} \mathrm{N}$ of $-33.5 \pm 4.1 \%$ measured in otolith aragonite deposited in 1959 was in statistical agreement with measurements on seawater DIC collected in July 1957. Measurements of ${ }^{14} \delta^{S}$ in Barents Sea DIC in 1965 and 1966 were $73.2 \pm 9.9 \%$ $(\mathrm{n}=2)$ and $77.6 \pm 6.4 \%$ o, respectively and are in statistical agreement with ${ }^{14} \delta^{\mathrm{S}}{ }_{\mathrm{N}}$ of $78.7 \pm 5.9 \%$ measured in a cod otolith from a fish spawned in 1965. In 1990 Barents Sea ${ }^{14} \delta^{\mathrm{S}} \mathrm{N}$ measured in seawater DIC had decreased to $58.9 \pm 2.2 \%$ o $(n=5)$, very similar to otolith ${ }^{14} \delta^{\mathrm{S}}{ }_{\mathrm{N}}$ of $56.0 \pm 7.0 \%$ in the same year.

Individual measurements of ${ }^{14} \delta^{\mathrm{S}}{ }_{\mathrm{N}}$ in surface seawater DIC in polar latitudes of the northeast Atlantic were made by the GEOSECS and TTO expeditions in 1972 and 1982, respectively (Figure 4). These measurements were made west of the warm inflow of NACW and the Arctic Frontal Zone (AFZ) and within Arctic Water (AW) dominated by East Greenland Current Water (EGCW) and are not directly comparable with measurements from the cod otolith proxy. The AFZ represents the meridional interface between warm, saline waters derived from the North Atlantic Drift (NAD), Norwegian Atlantic Water (NAW) to the east, and colder, less saline AW from the Greenland Sea to the 
Table $2{ }^{14} \mathrm{C}$ in seawater (DIC) and mollusc shell $\mathrm{Ca} \mathrm{CO}_{3}$ at various times in the Barents Sea

\begin{tabular}{|c|c|c|c|c|c|c|c|c|}
\hline $\begin{array}{l}\text { Laboratory } \\
\text { reference }\end{array}$ & $\begin{array}{l}\text { Sample } \\
\text { date }\end{array}$ & $\begin{array}{l}\text { Sample } \\
\text { location }\end{array}$ & $\begin{array}{c}\text { Sample } \\
\text { type }\end{array}$ & Depth & Salinity & Temp. & $\begin{array}{c}{ }^{14} \delta^{S}{ }_{N} \\
(\% o)\end{array}$ & $\begin{array}{c} \pm \text { error } \\
(\% 0)\end{array}$ \\
\hline ST-335 & 3-Jul-57 & $72^{\circ} 51^{\prime} \mathrm{N} 41^{\circ} 51^{\prime} \mathrm{E}$ & Seawater DIC & 337 & 34.98 & -0.7 & -38 & 6 \\
\hline SV-00001 & $15-$ Nov-65 & $72^{\circ} 32^{\prime} \mathrm{N} 20^{\circ} 04^{\prime} \mathrm{E}$ & Seawater DIC & 4 & 34.81 & & 80.2 & 11.0 \\
\hline SV-00002 & 21-Nov-65 & $74^{\circ} 40^{\prime} \mathrm{N} 39^{\circ} 00^{\prime} \mathrm{E}$ & Seawater DIC & 4 & 35.19 & & 66.2 & 10.0 \\
\hline SV-00008 & 2-Jun-66 & $74^{\circ} 14^{\prime} \mathrm{N} 20^{\circ} 11^{\prime} \mathrm{E}$ & Seawater DIC & 4 & 34.95 & 0.1 & 73.1 & 9.0 \\
\hline LA3-00001 & 23-Jul-90 & $79^{\circ} 22^{\prime} \mathrm{N} 30^{\circ} 20^{\prime} \mathrm{E}$ & Seawater DIC & 6 & 33.68 & 4.8 & 56.2 & 4.2 \\
\hline LA4-00001 & 27-Jul-90 & $79^{\circ} 01^{\prime} \mathrm{N} 41^{\circ} 54^{\prime} \mathrm{E}$ & Seawater DIC & 5 & & 2.7 & 60.3 & 3.8 \\
\hline LA2-00002A & 23-Jul-90 & $78^{\circ} 12^{\prime} \mathrm{N} 29^{\circ} 50^{\prime} \mathrm{E}$ & Seawater DIC & 50 & 33.58 & 3.5 & 59.4 & 4.6 \\
\hline LA5-00002A & 30-Jul-90 & $80^{\circ} 31.0^{\prime} \mathrm{N} 29^{\circ} 12.0^{\prime} \mathrm{E}$ & Seawater DIC & 5 & 33.63 & -1.1 & 57 & 4.6 \\
\hline GEOS-17 & 18-Aug-72 & $74^{\circ} 56^{\prime} \mathrm{N} 1^{\circ} 07^{\prime} \mathrm{W}$ & Seawater DIC & 4 & & & 33.9 & 4 \\
\hline TTO-159 & 8-Jun-81 & $68^{\circ} 43.5^{\prime} \mathrm{N} 10^{\circ} 33.6^{\prime} \mathrm{W}$ & Seawater DIC & 12 & & & 55.7 & 4 \\
\hline $\mathrm{T}-1534$ & 1857 & $69^{\circ} 39^{\prime} \mathrm{N} 18^{\circ} 58^{\prime} \mathrm{E}$ & Chlamys islandicus & & & & -56.0 & 6.0 \\
\hline $\mathrm{T}-1536$ & 1857 & $70^{\circ} 04^{\prime} \mathrm{N} 29^{\circ} 45^{\prime} \mathrm{E}$ & Astarte crenata & & & & -55.0 & 6.0 \\
\hline $\mathrm{T}-1535$ & 1876 & $70^{\circ} 30^{\prime} \mathrm{N} 28^{\circ} 30^{\prime} \mathrm{E}$ & Astarte crenata & 232 & & & -61.0 & 9.0 \\
\hline $\mathrm{T}-1537$ & 1900 & $74^{\circ} 07^{\prime} \mathrm{N} 19^{\circ} 04^{\prime} \mathrm{E}$ & Chlamys islandicus & 90 & & & -57.0 & 6.0 \\
\hline $\mathrm{T}-958$ & 1922 & $70^{\circ} 16^{\prime} \mathrm{N} 23^{\circ} 24^{\prime} \mathrm{E}$ & Mytilus edulis & $0-10$ & & & -63.0 & 9.0 \\
\hline $\mathrm{T}-1538$ & 1926 & $77^{\circ} 40^{\prime} \mathrm{N} 14^{\circ} 16^{\prime} \mathrm{E}$ & Chlamys islandicus & $120-190$ & & & -60.0 & 6.0 \\
\hline $\mathrm{T}-1539$ & 1925 & $78^{\circ} 07^{\prime} \mathrm{N} 14^{\circ} 08^{\prime} \mathrm{E}$ & Chlamys islandicus & $150-165$ & & & -57.0 & 6.0 \\
\hline $\mathrm{T}-1540$ & 1878 & $78^{\circ} 15^{\prime} \mathrm{N} 15^{\circ} 36^{\prime} \mathrm{E}$ & Astarte borealis & & & & -66.0 & 9.0 \\
\hline $\mathrm{T}-1541$ & 1878 & $79^{\circ} 34^{\prime} \mathrm{E} 10^{\circ} 40^{\prime} \mathrm{E}$ & Astarte borealis & $40-80$ & & & -67.0 & 9.0 \\
\hline
\end{tabular}


west (Van Aken et al. 1995). The distribution of Arcto-Norwegian cod spawning grounds and catches of 0-group cod in the Barents Sea indicate that these fish do not occur to the west of the AFZ during these life history stages. Therefore, ${ }^{14} \mathrm{C}$ from the cod otoliths is representative of NAW, whereas the GEOSECS and TTO measurements north of $68^{\circ} \mathrm{N}$ latitude would have AW as their predominate influence. This west-east transition in water mass characteristics is reflected in the difference between GEOSECS, TTO, and otolith ${ }^{14} \delta^{S}{ }_{N}$ data (Figure 4). Otolith ${ }^{14} \delta^{S}{ }_{N}$ values were about 35\% greater than the GEOSECS and TTO polar North Atlantic measurements, collected in 1972 and 1981, respectively.

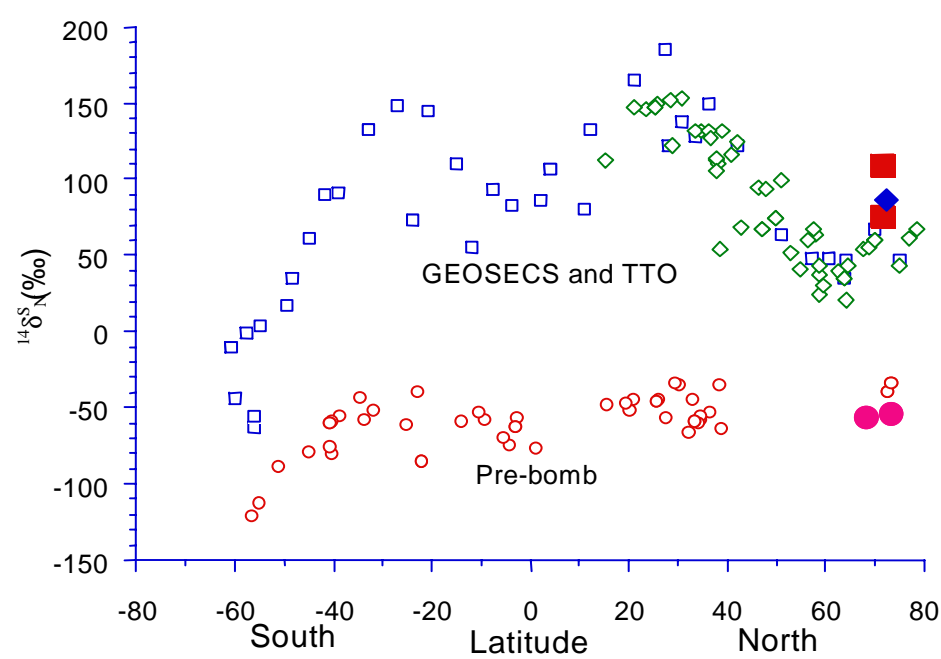

Figure $4{ }^{14} \mathrm{C}$ data $\left({ }^{14} \delta^{\mathrm{S}} \mathrm{N}\right)$ in surface seawater DIC made by the GEOSECS (open squares) and TTO (open diamonds) expeditions in 1972 and 1982, respectively. These data are compared with pre-bomb otolith data (filled circles) and otolith data from 1972 and 1982 (filled squares). Pre-bomb data (open circles) are from Broecker and Peng (1982).

\section{Comparisons with Temperate and Subtropical Ocean ${ }^{14} \mathrm{C}$ Time Series}

Several ${ }^{14} \mathrm{C}$ time series have been developed for the subtropical, tropical, and temperate North Atlantic on the basis of hermatypic corals (Druffel and Linick, 1978; Nozaki et al. 1978) and a bivalve (Weidman and Jones 1993) and these series display several features in common with Barents Sea ${ }^{14} \mathrm{C}$ from otoliths (Figure 5).

Pre-industrial ${ }^{14} \delta^{\mathrm{S}}{ }_{\mathrm{N}}$ value in Florida coral was estimated to be $-51 \%$ and declined to $-62 \%$ by 1954 due to the burning of fossil fuels (Druffel and Linick 1978). No pre-industrial data were collected from the cod otoliths, but the earliest data from 1919 and 1920 had a mean of $-49 \%$, which is in good agreement with the Florida coral data.

Pre-bomb, post-industrial ${ }^{14} \delta^{S}{ }_{N}$ value in Arcto-Norwegian cod between 1950 and 1955 was -52.5 $\pm 6.1 \%$ o $(n=3)$ a value that falls between data from a similar time period derived from Florida and Bermuda corals. For Bermuda corals Nozaki et al. (1978) measured a pre-bomb value of $-50 \%$ o in 1950 and Druffel (1989) determined pre-bomb ${ }^{14} \delta^{S_{N}}$ value to be $-48.3 \pm 4.9(n=5)$. Florida corals contained slightly less ${ }^{14} \mathrm{C}$ and averaged $-59.5 \pm 5.2 \%$ ( $\left.\mathrm{n}=6\right)$ between 1950 and 1955 (Druffel 


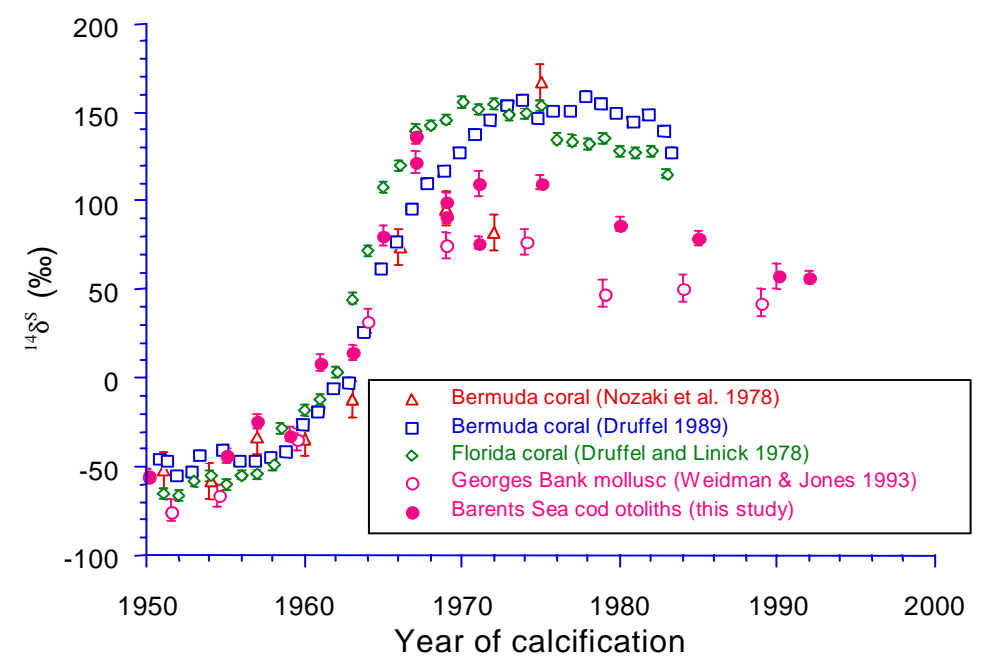

Figure 5 Comparison of several ${ }^{14} \mathrm{C}$ series developed for the subtropical, tropical, and temperate North Atlantic on the basis of corals, molluscs and cod otoliths

and Linick 1978). Data from a bivavle, Arctica islandica, collected at $41^{\circ} \mathrm{N}$ latitude provided a ${ }^{14} \delta^{\mathrm{S}}{ }_{\mathrm{N}}$ series that is representative of water dominated by a deepwater source derived from polar latitudes (Weidman and Jones 1993) and pre-bomb ${ }^{14} \delta^{\mathrm{S}}{ }_{\mathrm{N}}$ was $-70.6 \%$, significantly lower than that measured in the Arcto-Norwegian cod otoliths from north of $70^{\circ} \mathrm{N}$ latitude.

Bomb ${ }^{14} \mathrm{C}$ is clearly present in Arcto-Norwegian cod otoliths from fish spawned in 1957 when ${ }^{14} \delta^{\mathrm{S}} \mathrm{N}$ was $-25.8 \pm 4.1 \%$ and this is similar to the time when bomb ${ }^{14} \mathrm{C}$ was first detectable in corals from Bermuda (Druffel 1989), Florida (Druffel and Linick 1978) and the Pacific (Druffel 1987), but somewhat earlier than the first evidence of bomb ${ }^{14} \mathrm{C}$ from the temperate bivalve from Georges Bank (Weidman and Jones 1993).

The Barents Sea ${ }^{14} \mathrm{C}$ series appears to be in phase with both the Florida (Druffel and Linick 1978) and Bermuda coral series (Druffel 1989) during the 1960 s when bomb ${ }^{14} \mathrm{C}$ was increasing most rapidly. In 1967, cod otolith ${ }^{14} \delta^{\mathrm{S}}{ }_{\mathrm{N}}$ increased dramatically to $128.1 \pm 8.7 \%$ o $(\mathrm{n}=2)$ and this was significantly greater than mean ${ }^{14} \delta^{\mathrm{S}}{ }_{\mathrm{N}}$ of $110.5 \%$ in Bermuda corals for a similar time period (Druffel 1989), but less than a ${ }^{14} \delta^{\mathrm{S}}{ }_{\mathrm{N}}$ of $140 \%$ measured in corals from Florida (Druffel and Linick 1978). Although this correspondence between Florida and Barents Sea data suggests similar levels of atmospheric ${ }^{14} \mathrm{C}$ inputs, there are significant differences in later years that are likely to be related to differences in vertical mixing and require more detailed analysis for interpretation.

\section{Comparisons with Atmospheric ${ }^{14} \mathrm{C}$ Time Series}

Atmospheric records from Fruholmen (Nydal and Løvseth 1996) and ocean records from the Barents Sea both show a gradual decrease in ${ }^{14} \delta^{\mathrm{S}} \mathrm{N}$ after the peak in the middle to late 1960s (Figure 6). This gradual decrease indicates that the ${ }^{14} \mathrm{C}$ pulse associated with atmospheric atomic tests has yet to equilibrate with surface waters of the ocean and that ocean ${ }^{14} \mathrm{C}$ continues to be distributed to other pools of inorganic and organic carbon. Continued input of ${ }^{14} \mathrm{C}-$ free $\mathrm{CO}_{2}$ associated with the burning of fossil fuels will also contribute to the decline in atmospheric ${ }^{14} \mathrm{C}$, but this effect is more difficult to confirm in Barents Sea waters. The decrease in ${ }^{14} \delta^{\mathrm{S}} \mathrm{N}$ in the polar atmosphere and surface Barents Sea between the years 1975 to 1992 is about 15\%o per year and 3\%o per year, respectively. This sug- 
gests that the flux of ${ }^{14} \mathrm{C}$ between the atmosphere and ocean is five times greater than its movement from the surface Barents Sea or incorporation into other carbon pools. This apparent slow turnover time for ${ }^{14} \mathrm{C}$ in the Barents Sea may be linked to the magnitude of volume transport into the southern Barents Sea (e.g. 1.6 Sv from the NAC; Loeng et al. 1993).

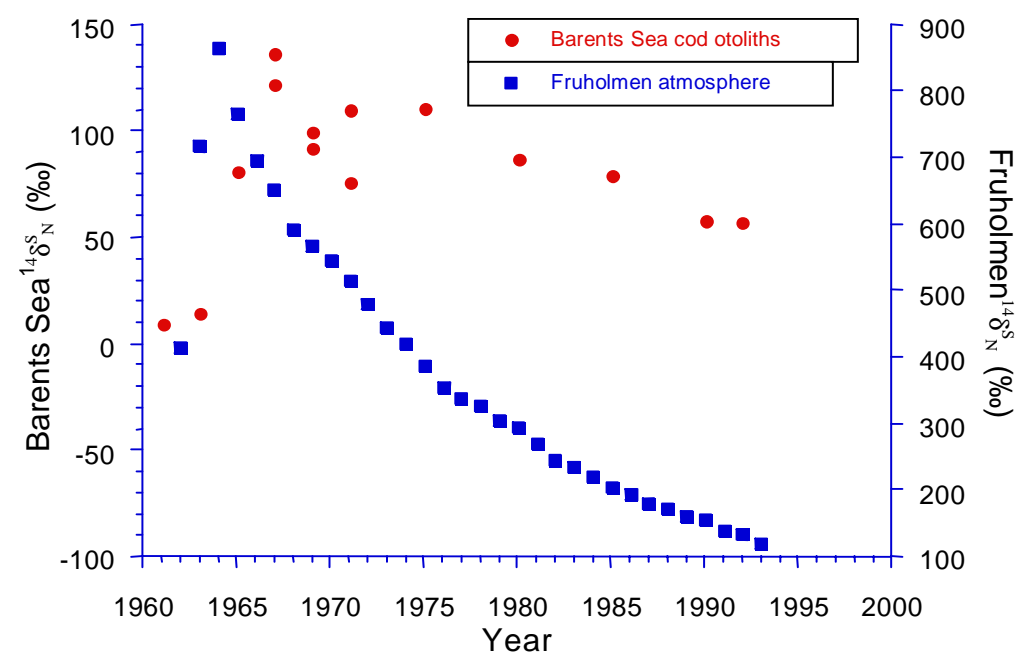

Figure 6 Comparison of atmospheric ${ }^{14} \mathrm{C}$ records from Fruholmen and ocean records (cod otoliths) from the Barents Sea

Atmospheric ${ }^{14} \mathrm{C}$ measured at Fruholmen between 1970 and 1993 is well described by an exponential function with the highest rate of decline from the mid-1960s to mid-1970s (Figure 7). The difference between ${ }^{14} \delta_{\mathrm{N}}^{\mathrm{S}}$ measured at Froholmen and in the Barents Sea declined at a rate of about $37 \%$ o during this time, whereas the rate of decline was only $12 \%$ oper year from the mid-1970s to the early 1990s. The differential between Fruholmen and Barents Sea ${ }^{14} \delta^{\mathrm{S}}{ }_{\mathrm{N}}$ near the bomb peak was about $700 \%$ and would have resulted in increased rate of ${ }^{14} \mathrm{C}$ flux to the surface ocean.

Data on ${ }^{137} \mathrm{Cs}$ in Barents Sea surface waters show peaks in the mid-1960s and around 1980 (Kershaw and Baxter 1993). The peak in the 1980 s is associated with releases of ${ }^{137} \mathrm{Cs}$ from the Sellafield Reprocessing Plant off the west coast of Great Britain, whereas the peak in the 1960s resulted from fallout from atmospheric atomic tests, a large number of which were conducted between 1957 and 1963 at the Novaya Zemlya test site that borders the eastern Barents Sea. Given the close proximity of this site to the nursery grounds of 0-group Arcto-Norwegian cod, it is possible that this area was exposed to close-in fallout ${ }^{14} \mathrm{C}$ produced by atomic testing. Clearly, there are several factors in the mid-1960s that would contribute to a relatively early peak of ${ }^{14} \mathrm{C}$ in the Barents Sea. Time series of ${ }^{14} \mathrm{C}$ from hermatypic corals in the tropical North Pacific show peak activities in the late 1960 s to early 1970s and this was likely to be a manifestation of the corals' close proximity to atmospheric atomic tests in the North Pacific (Druffel 1987).

\section{CONCLUSION}

Cod otoliths provide the first pre- and post-bomb time series of ${ }^{14} \mathrm{C}$ from polar waters. Changes in both ocean and atmospheric inputs of ${ }^{14} \mathrm{C}$ are likely to have a strong influence on Barents $S e a{ }^{14} \mathrm{C}$. Close-in fallout from atmospheric tests at Novaya Zemlya may have resulted in a relatively early 


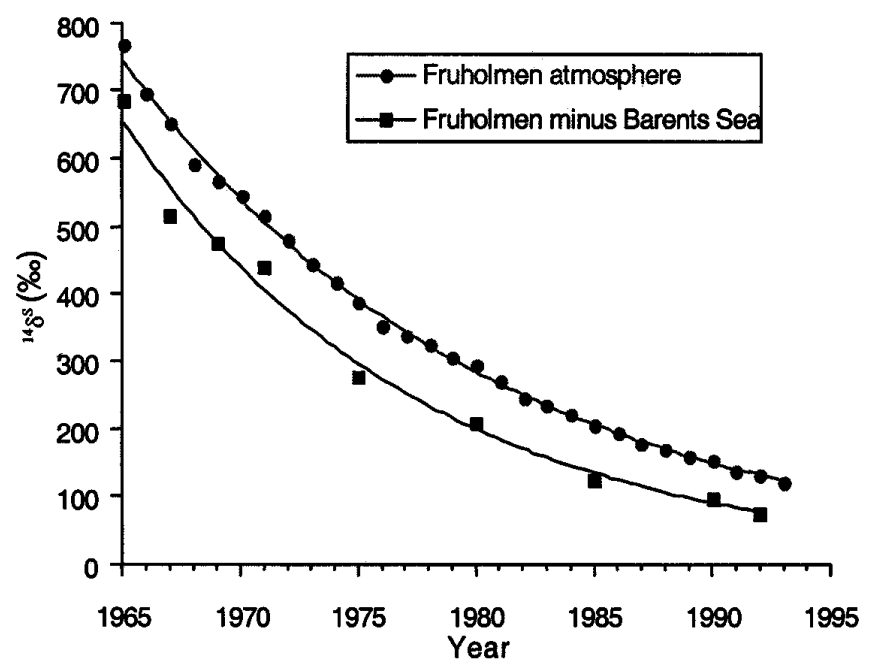

Figure 7 Atmospheric ${ }^{14} \mathrm{C}$ measured at Fruholmen between 1965 and 1993, and the difference between atmospheric Fruholmen records and oceanic Barents Sea records

peak in ${ }^{14} \mathrm{C}$ in the Barents Sea in 1967 , earlier than measured in other Atlantic Ocean time series. Although the otolith-derived series of ${ }^{14} \mathrm{C}$ data from the Barents Sea has a relatively coarse temporal resolution, it suggests that more detailed data sets produced from a similar source could be used to investigate annual changes in ocean circulation as has been achieved by others using corals (e.g. Druffel 1989). Further understanding of production of deepwater from the northeastern region of the Atlantic could be derived from a similar study of otoliths from Icelandic stocks of cod, another stock of cod with a well-defined distribution during early life. The 0-group cod from these stocks are present in water derived from the East Greenland and East Icelandic Currents. Other species of fish with long histories of commercial exploitation and relatively long life spans can enhance our understanding of ocean circulation and ${ }^{14} \mathrm{C}$ flux in a broad range of habitats.

\section{ACKNOWLEDGMENTS}

We thank Justine Johnston (Australian National University) for sculpting the otoliths and Hildegunn Mjanger and Lisbet Solbakken (Institute of Marine Research) for assistance with figures. The measurements were performed in the period 1994-1995, and the main financial support was provided from the Norwegian Research Council. Also support from the NSF-Arizona laboratory in Tucson is greatfully acknowledged.

\section{REFERENCES}

Aagaard K, Carmack EC. 1989. The role of sea ice and other fresh water in the arctic circulation. Journal of Geophysica Research 94:14,485-98.

Anonymous. 2000. Report of the Arctic Fisheries Working Group. August-September 1999. ICES CM 2000/ Assess: ACFM 4. $171 \mathrm{p}$.

Broecker WS, Peng T-H. 1982. Tracers in the sea. A publication from the Lamont-Doherty Observatory. Palisades, New York: Columbia University.

Campana SE, Mohn RK, Smith SJ, Chouinard GA.1996. Spatial implications of a temperature-based growth model for Atlantic cod (Gadus morhua) off the eastern coast of Canada. Canadian Jouirnal of Fisheries and Aquatic Sciences 53(12):2912-14.

Donahue DJ, Linick TW, Jull AJT. 1990. Isotope-ratio and background corrections for accelerator mass spectrometry radiocarbon measurements. Radiocarbon 32(2):135-42.

Dragesund O, Gjøsaeter J. 1988. The Barents Sea. In: Postma, Zijlstra, editors. Ecosystem of the world 27. Continental Shelves. Elsevier. p 339-61.

Druffel EM., Linick TW. 1978. Radiocarbon of annual 
coral rings of Florida. Geophysical Research Letters 5: 913-6.

Druffel EM. 1987. Bomb radiocarbon in the Pacific: annual and seasonal timescale variations. Journal of $\mathrm{Ma}$ rine Research 45:667-98.

Druffel EM. 1989. Decade time scale variability of ventilation in the North Atlantic: high-precision measurement of bomb radiocarbon in banded corals. Journal of Geophysical Research 94:3271-85.

Gislefoss J, Nydal R, Skjelvan I, Nes A, Holmén K, Sonninen E, Østerhus S. 1995. Carbon profiles in the Nordic Seas, a report on cruise tracks with R/V Lance and R/V Håkon Mosby summer 1991, and R/V Johan Hjort summer 1992. Radiological Dating Laboratory Report (2). $61 \mathrm{p}$

Kalish JM. 1993. Pre- and post-bomb radiocarbon in fish otoliths. Earth and Planetary Science Letters 114: $549-54$.

Kalish JM 1995. Radiocarbon and fish biology. In: Secor DH, Dean JM, Campana SE, editors. Recent Developments in Fish Otolith Research. Columbia, South Carolina: University of South Carolina Press. p 637 53

Kalish JM, Beamish RJ, Brothers EB, Casselman JM, Francis RICC, Mosegaard H, Panfili J, Prince ED, Thresher, RE, Wilson, CA, Wright PJ. 1995. Standard terms for otolith research. In: Secor DA, Dean JM, Campana SE, editors. Recent developments in fish otolith research, University of South Carolina Press. p 723-29.

Kershaw PJ, Baxter AJ. 1993. Transfer of reprocessing wastes from NW Europe to the Arctic. In: Strand P, Holm E, editors. Environmental radioactivity in the Arctic and Antarctic. Proceedings of the International Conference on Environmental Radioactivity in the Arctic and Antarctic, Kirkenes, Norway. p 103-7.

Loeng H, Ozhigin, V, Ådlandsvik B, Sagen H. 1993. Current measurements in the northeastern Barents Sea. ICES Statuatory Meeting. $22 \mathrm{p}$.

Mangerud J, Gulliksen S. 1975. Apparent radiocarbon ages of recent marine shells from Norway, Spitsbergen, and Arctic Canada. Quaternary Research 5:26373.

Midtun L. 1985. Formation of dense bottom water in the Barents Sea. Deep Sea Research 32(10):1233-41.

Mook WM, van der Plicht J. 1999. Reporting ${ }^{14} \mathrm{C}$ activities and concentrations. Radiocarbon 41(3):227-39.

Nozaki Y, Rye DM, Tkkurckean KK, Dodge RE. 1978. A 200 year record of carbon-13 and carbon-14 variations in Bermuda coral. Geophysical Research Letters
5:825-8.

Nydal R, Løvseth K. 1996. Carbon-14 measurements in atmospheric $\mathrm{CO}_{2}$ from Northern and Southern hemisphere sites, 1962-1993. Zumbrunn V, Boden TA, editors. Carbon Dioxide Information Analysis Center, Oak Ridge National Laboratory, Oak Ridge, Tennessee, USA. ORNL/CDIAC-93, NDP-057:1-26, A1A6, B1-B24.

Nydal R. 1998. Carbon-14 measurments in surface water $\mathrm{CO}_{2}$ from the Atlantic, Indian and Pacific Oceans, 1965-1994. Brenkert AL, Boden TA, editors. Carbon Dioxide Information Analysis Center, Oak Ridge National Laboratory, Oak Ridge, Tennessee, USA. ORNL/CDIAC-104, NDP-057A:1-75, A3-A28 (http: //cdiac.esd.ornl.gov./oceans/home.html).

Nydal R, Gislefoss JS. 1996. Further application of bomb $\mathrm{C}-14$ as a tracer in the atmosphere and ocean. Radiocarbon 38(3):389-406.

Nydal R, Gislefoss JS, Skjelvan I, Blindheim J, Foldvik A, Vinje T, Østerhus S. 1991. Measurements of carbon profiles in the Nordic Seas. Norsk Polarinstitutt Rapportserie 75 . Oslo. $43 \mathrm{p}$.

Østlund HG, Engstrand LG. 1963. Stockholm natural radiocarbon measurements 5. Radiocarbon 5:203-27.

Rollefsen G. 1933. The otoliths of the cod. Fiskeridirektoratets Skrifter serie Havundersøkelser 4(3):17 p.

Saetersdal G, Loeng H. 1987. Ecological adaptation of reproduction in northeast Arctic cod. Fisheries Research 5:253-70.

Secor DH, Dean JM, Campana SE, editors. 1995. Recent developments in fish otolith research. Columbia, South Carolina: University of South Carolina Press.

Stuiver M, Polach H. 1977. Reporting of ${ }^{14} \mathrm{C}$ data. Radiocarbon 19(3):355-63.

Sundby S. 1994. The influence of bio-physical processes on fish recruitment in an arctic-boreal ecosystem. Doctor of Philosophy thesis. Norway: University of Bergen. $189 \mathrm{p}$.

van Aken HM, Budeus G, Hahnel M. 1995. The anatoy of the Arctic Frontal Zone in the Greenland Sea. Journal of Geophysical Research-Oceans 100 (C8): 15,999-16,014.

Wassmann P, Slagstad D. 1991. Annual dynamics of carbon flux in the Barents Sea: preliminary results. Norsk Geologisk Tidsskrift 71:231-4.

Weidman CR, Jones GA. 1993. A shell-derived time history of bomb ${ }^{14} \mathrm{C}$ on Georges Bank and its Labrador Sea implications. Journal of Geophysical Research 98(C8):14,577-588. 